\title{
A Nano-Sepiolite Clay Electrochemical Sensor for the Rapid Electro-Catalytic Detection of Hydroquinone in Cosmetic Products
}

\author{
Sevda Aydar, ${ }^{1}$ Dilek Eskiköy Bayraktepe ${ }^{2}$ Hayati Filik ${ }^{2}$ and Zehra Yazan ${ }^{2,}$ \\ ${ }^{1}$ Faculty of Engineering,Department of Chemistry, Istanbul University, 34320 Avclar, Istanbul, Turkey \\ ${ }^{2}$ Ankara University, Faculty of Science, Chemistry Department, 06560 Ankara, Turkey \\ * Corresponding author: E-mail: zehrayazan67@gmail.com \\ Phone: $+903122126720 / 1284$ fax: +903122232395
}

Received: 13-07-2018

\begin{abstract}
In this paper, a simple and sensitive electrochemical nano-sensor was developed for the analysis of hydroquinone based on sepiolite clay modified carbon paste sensor by using differential pulse adsorptive stripping voltammetry and square wave adsorptive stripping voltammetry. Surface morphology of sensors was characterized by using scanning electron microscopic technique, electrochemical impedance spectroscopy, and cyclic voltammetry. Electrochemical redox properties of hydroquinone were investigated by cyclic voltammetry. The oxidation peak current of hydroquinone in differential pulse and square wave adsorptive stripping voltammetry changes linearly in the concentration range of 0.01-700 $\mu \mathrm{molL}^{-1}$ and $0.01-700 \mu \mathrm{molL}^{-1}$, respectively. Excellent limit of detection (LOD) and limit of quantification (LOQ) values were found as $0.01096 \mu \mathrm{molL}^{-1}$ and $0.03654 \mu \mathrm{molL}^{-1}$ for differential pulse, and $0.01031 \mu \mathrm{molL}^{-1}$ and $0.03438 \mu \mathrm{molL}^{-1}$ for square wave adsorptive stripping voltammetry, respectively. Additionally, the newly proposed sensor was applied to the analysis of hydroquinone in cosmetic cream with satisfying results.
\end{abstract}

Keywords: Hydroquinone; sepiolite clay; carbon paste electrode; cosmetic cream; voltammetry

\section{Introduction}

Hydroquinone (HQ) is a phenol derivative with antioxidant properties that can cause toxicity in several organs, such as the kidneys. It is used as a topical treatment for skin hyperpigmentation in various cosmetic products. ${ }^{1}$ It is metabolized mainly to glutathione conjugates and forms mutagenic DNA adducts in in-vitro systems. Due to its high toxicity, several methods have been established for the determination, such as high performance liquid chromatography, ${ }^{2}$ fluorescence, ${ }^{3}$ chemiluminescence, ${ }^{4}$ spectrophotometry, ${ }^{5-6}$ gas chromatography-mass spectrometry, ${ }^{7}$ capillary electro-chromatography, ${ }^{8}$ and electrochemical methods. ${ }^{9-13}$

Most of the methods, in particular chromatographic methods, are both time consuming and based on the use of organic liquids in excess volumes. Electrochemical techniques for hydroquinone assay are cost effective, fast and highly sensitive. The non-destructive nature and extremely low sample consumption makes them one of the preferred techniques. ${ }^{11}$
Electrochemical devices for use in clinical, cosmetic and environmental monitoring are developing rapidly. ${ }^{14,15}$ Many researchers focused on the design of the electrochemical sensors using nano electrode materials to modify the electrode so as to improve the quality of signal. Among many electrode improvement components, carbon nanotubes, ${ }^{16}$ graphene,${ }^{17}$ nano-sized metal oxides, ${ }^{18}$ and clay minerals ${ }^{19}$ proved to be promising.

Nanomaterials provide a conductive sensing interface and have catalytic effects on the electrochemical process. On the other hand, the clay electrode contributes to the electrical conductivity and catalytic effect to electron-transfer rates. We chose sepiolite (natural clay mineral) for our sensor composition because of its high surface area and surface activity. ${ }^{19}$

Here, we extend the investigations on the use of sepiolite clay for the analysis of HQ in cosmetic products. We developed a sensitive, selective, and reliable adsorptive stripping anodic voltammetric methods for the determination of HQ with a high precision and accuracy together with a wide linear range and low limit of detection. 


\section{Experimental}

\section{1. Reagents and Apparatus}

Sepiolite clay, graphite powder, mineral oil and all solvents were supplied from Sigma. HQ was also supplied from Merck and other used chemicals were analytical grade. The stock solution of HQ $\left(1.0 \times 10^{-3} \mathrm{molL}^{-1}\right)$ was prepared by dissolving solid $\mathrm{HQ}$ in water and kept at $+4^{\circ} \mathrm{C}$ until experiment. $0.04 \mathrm{molL}^{-1}$ Britton-Robinson buffer was used as the supporting electrolyte.

All electrochemical measurements were performed by using CHI 660C (from USA) and C3 cell stand (BASi) with a solid electrode system. $\mathrm{Ag} / \mathrm{AgCl}\left(3.0 \mathrm{molL}^{-1} \mathrm{NaCl}\right.$, BAS MF-2052) was used as reference electrode, NSC/CPE and $\mathrm{BCPE}$ sensors as working electrodes, and platinum wire electrode (BAS MW-1032) as auxiliary electrode.

Before all assays, $\mathrm{pH}$ was measured with a HANNA Instruments HI2211 $\mathrm{pH} / \mathrm{ORP}$ meter with an accuracy of $\mathrm{pH} \pm 0.01$. Double-distilled water was supplied mpMINIpure system. All assays were carried out at $25^{\circ} \mathrm{C}$.

Scanning electron microscopic (SEM) images were recorded on Carl Zeiss AG, EVO ${ }^{\circledR} 50$ Series.

\section{2. Sensor Preparation Procedure}

Bare carbon paste (BCPE) and modified carbon paste (NSC/CPE) electrodes were prepared for comparative purposes. For the preparation of modified carbon paste electrodes, the varying proportions of sepiolite 3.3\% (1.0/30); $5 \%$ (1.5/30); 6.7\% (2.0/30); 8.3\% (2.5/30) with proper masses of graphite powder and mineral oil $(10 \mu \mathrm{L})$, making the final weight to $30 \mathrm{mg}$, were mixed in a mortar and ground for $5 \mathrm{~min}$ with a pestle. Both the bare containing $30 \mathrm{mg}$ graphite powder and modified paste were filled into the hole of the electrode body and the electric contact was made with a copper wire in the center of the cylindrical body. The outward surface of the electrode was polished with a piece of polishing paper until it had a shiny surface. Before all assays, the surface cleaning of carbon paste sensors was carried out by washing with water-ethanol mixture (1:1) before all experiments.

\section{3. Analytical Procedure}

The cyclic, differential pulse and square wave voltammetric experiments were carried out at room temperature in an electrochemical cell containing BR buffer solution and the required volume of hydroquinone standard solution. CV measurements were recorded by cycling the potential between -0.2 and $+1.0 \mathrm{~V}$ at a scan rate of 0.10 $\mathrm{Vs}^{-1}$. The adsorptive stripping square wave voltammetry (AdsSWV) measurements were performed by scanning the potential from 0.2 to $+0.8 \mathrm{~V}$ at a frequency of $20 \mathrm{~Hz}$, pulse amplitude of $0.025 \mathrm{~V}$, and with scan increments of $0.008 \mathrm{~V}$. The adsorptive stripping differential pulse voltammetry (AdsDPV) conditions were given as follows: ampli- tude: $0.05 \mathrm{~V}$, pulse width: $0.05 \mathrm{~s}$, sample width: $0.0167 \mathrm{~s}$, pulse period: $0.5 \mathrm{~s}$; HQ solutions of $8.0 \times 10^{-8} \mathrm{molL}^{-1}$ in the potential range of 0.2 to $+0.8 \mathrm{~V}$.

The solution was stirred at $400 \mathrm{rpm}$ at optimum stripping conditions. After the pre-concentration period, the stirring was stopped and voltammograms were recorded.

\section{4. Cream Sample Preparation}

Pharmaceutical and cosmetic cream samples (Expigment Cream 4\% HQ) were taken from pharmacy. The cream was kept at room temperature until assay. Known amounts of cream $(15 \mathrm{mg})$ were dissolved in $50 \mathrm{~mL}$ distilled water. The solution was shaken for $30 \mathrm{~min}$ in an ultrasonic bath to facilitate the complete dissolution of hydroquinone. This solution has served as the stock solution for the preparation of the samples for analysis. Appropriate volume of aliquot was taken from the clear part of solution and transferred into the working cells. The volume of the working solution was completed to $10 \mathrm{~mL}$ by BR buffer ( $\mathrm{pH} 2.0$ ).

\section{Results and Discussion}

\section{1. Optimum Composition of Sepiolite clay}

The composition of modified electrodes has a significant effect on electrochemical signal of modified electrodes by means of changing the sensitivity and selectivity of electrodes and redox potential shift. ${ }^{20}$ For this purpose, sepiolite clay electrodes were prepared with the different combinations in the range between $3.3 \%$ and $8.3 \%(w / w)$. Then the voltammetric responses of the modified electrodes were studied by $\mathrm{CV}$ technique in the presence of 1.0 $\times 10^{-4} \mathrm{molL}^{-1} \mathrm{HQ}$ in BR buffer solution $\mathrm{pH} 2.0$ (Fig. 1).

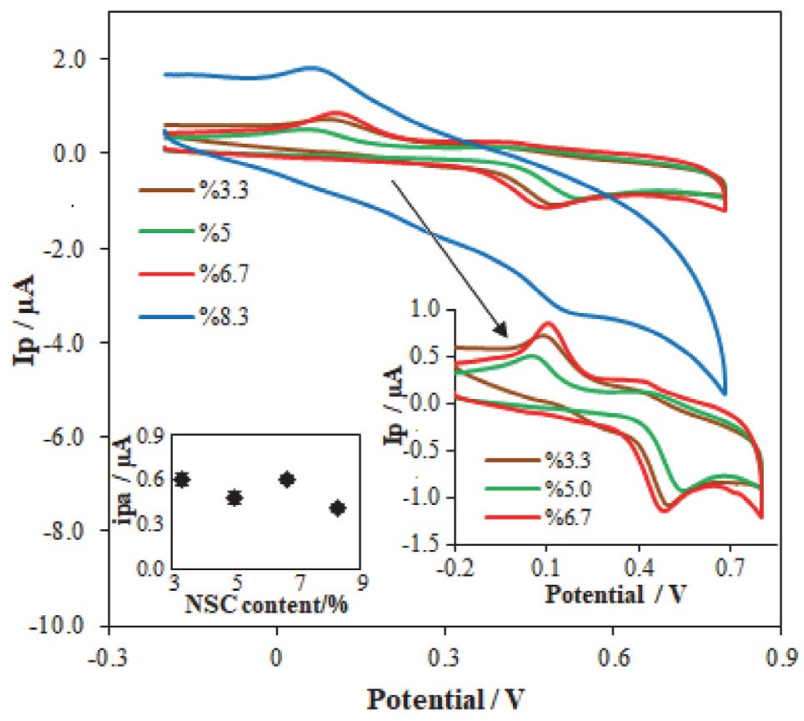

Fig. 1. Cylic voltammograms of $1.0 \times 10^{-4} \mathrm{molL}^{-1} \mathrm{HQ}$ in different compositions of NSC/CPE zoomed to specific composition range indicated with arrow in $\mathrm{pH} 2.0 \mathrm{BR}$ buffer at scan rate: $0.10 \mathrm{Vs}^{-1}$. 
As seen in Fig. 1, both obtained anodic and cathodic peak currents of HQ on sepiolite clay modified carbon paste electrode containing $6.7 \%$ sepiolite clay are higher than those obtained on sepiolite clay carbon paste electrodes with other percentages of clay. Also, the lowest potential difference between anodic and cathodic peak potential $\left(\Delta E_{\mathrm{p}}\right)$ value was obtained from sepiolite clay modified carbon paste electrode containing $6.7 \%$ sepiolite clay. Herein, the optimal modified electrode composition for the sepiolite sensor electrode was found as $6.7 \%$ sepiolite clay (2.0 mg sepiolite/30 mg paste, $93 \%$ graphite powder, and $10 \mu \mathrm{L}$ mineral oil).

\section{2. Characterization of Sensors}

Cylic voltammetry (CV), electrochemical impedance spectroscopy (EIS) and scanning electron microscopic (SEM) techniques were used for the surface characterization of the sensors (BCPE, NSC/CPE). Firstly, CV voltammograms of $5.0 \times 10^{-3} \mathrm{molL}^{-1} \mathrm{Fe}(\mathrm{CN})_{6}{ }^{3-/ 4-}$ in $\mathrm{KCl}$ $\left(0.1 \mathrm{molL}^{-1}\right)$ solution were used to compare the electrochemical properties of sensors (Fig. 2a). The trial experiments were carried out at a scan rate of $0.10 \mathrm{Vs}^{-1}$.

Clearly, the modified sensor gives rise to the best $\mathrm{CV}$ signal with the smaller $\Delta E_{\mathrm{p}}$ difference and the best peak current signal compared to the bare sensor in the standard solution. Then, at different scan rates, CV measurements were taken for the comparison of the specific areas of two sensors in $5.0 \times 10^{-3} \mathrm{molL}^{-1} \mathrm{Fe}(\mathrm{CN})_{6}{ }^{3-/ 4-}$ standard solution medium. Randles-Sevcik equations were evaluated by $\mathrm{CV}$ measurements at different scan rates $\left(i_{\mathrm{p}}\right.$ vs $\left.v^{1 / 2}\right)$. The active surface areas of NSC/CPE and BCPE were calculated by the means of $i_{\mathrm{p}}^{a}$ versus $v^{1 / 2}$ plot's slope and a known diffusion coefficient of $\mathrm{Fe}(\mathrm{CN})_{6}{ }^{3-/ 4-} 7.6 \times 10^{-6} \mathrm{~cm}^{2} \mathrm{~s}^{-1}$. ${ }^{21}$ The surface area of BCPE was evaluated to be $0.081 \pm$ $0.0017 \mathrm{~cm}^{2}$ and that of the NSC/CPE was $0.089 \pm 0.0013$ $\mathrm{cm}^{2}$. These results show 1.1 times increase in the surface areas of sensors.

The electrochemical impedance measurements were also used to compare the surface areas of modified electrode and bare electrode. The same redox couple was used as the standard analyte. Fig. $2 \mathrm{~b}$ displays the Nyquist plots obtained with the two electrodes. The diagrams in Fig. $2 \mathrm{~b}$ clearly show that NSC/CPE electrode displays the smallest electrical resistance which is indicative of the relatively higher surface area. The radius of semicircles is $\sim 4000 \Omega$ for NSC/CPE and $\sim 7000 \Omega$ for BCPE. It was attributed to accelerate electron-transfer rate of sepiolite clay as stated in the literature. ${ }^{19}$

SEM images of the BCPE and NSC/CPE surfaces exhibit their own characteristics. The BCPE sensor has nearly featureless, smooth surface (Fig. 2c), whereas the sur-
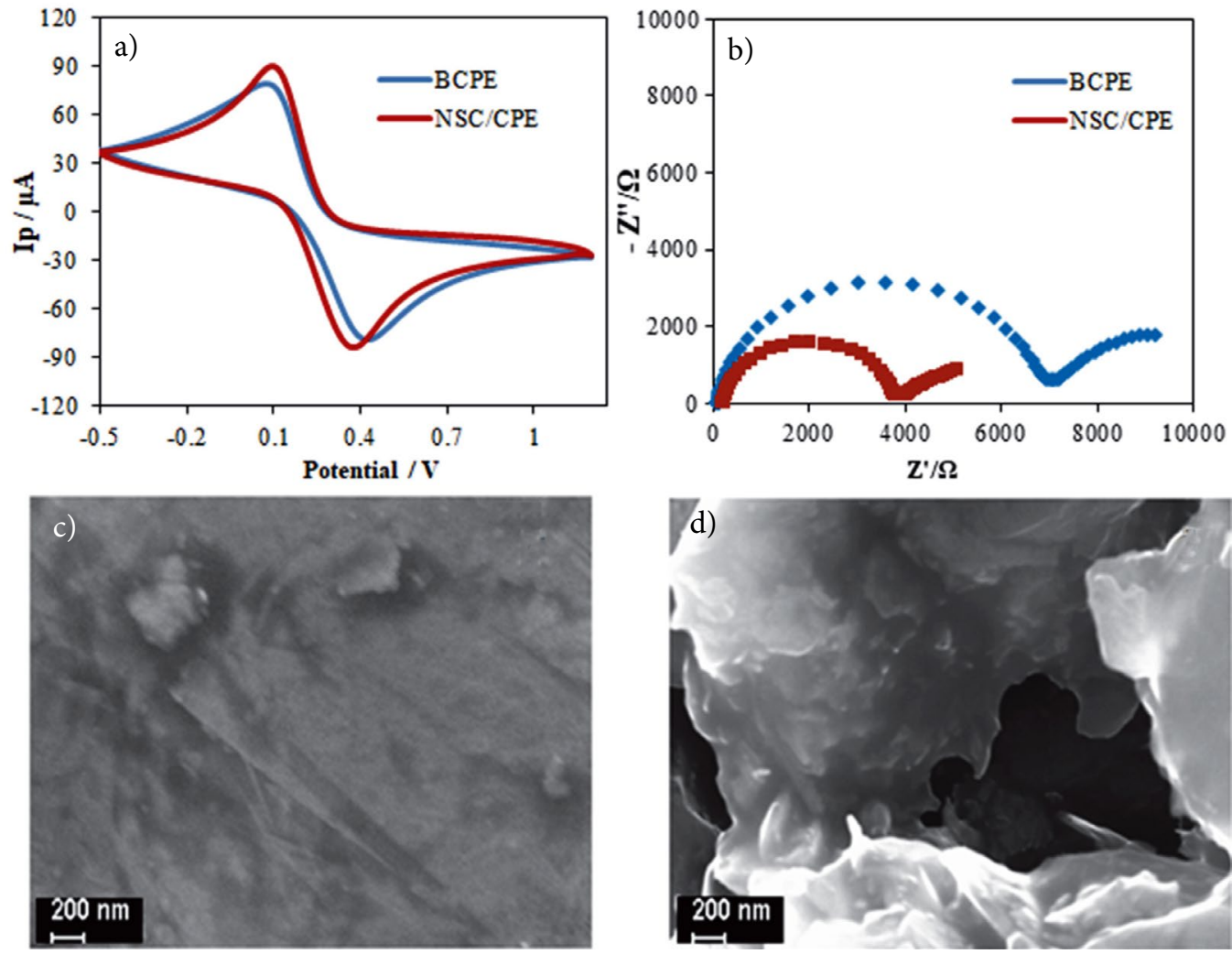

Fig. 2 a. Cylic voltammograms of $5.0 \mathrm{mmolL}^{-1} \mathrm{Fe}(\mathrm{CN})_{6}{ }^{3-/ 4-}$ in $0.1 \mathrm{molL}^{-1} \mathrm{KCl}$ solution on $\mathrm{BCPE}$ and NSC/CPE $\left(v: 0.1 \mathrm{Vs}^{-1}\right)$. b. Nyquist diagrams of BCPE and NSC/CPE in the same conditions (amplitude: $0.005 \mathrm{~V}$, frequency range of 0.05-100000 Hz,). SEM images of (c) BCPE, (d) NSC/CPE electrodes. 
face morphology of the NSC/CPE sensor exhibit typical holes indicating a larger specific surface area (Fig. 2d).

\section{3. Electrochemical Behavior of $\mathrm{HQ}$}

Cyclic voltammetry is one of the most suitable methods to investigate the electrochemical behavior of the analyte in different modified electrodes. The comparison of current and potential responses of HQ on the two electrodes was studied by cyclic voltammetry in $0.04 \mathrm{M}$ Britton-Robinson buffer ( $\mathrm{pH} 2.0$ ) solution at the scan rate value of $0.10 \mathrm{Vs}^{-1}$ (Fig. 3). As can be seen in Fig. 3, using nano sepiolite clay modified electrode, the well-defined oxidation peak for HQ was obtained. NSC/CPE electrode produces almost 1.4 times higher oxidation current signal compared to bare electrode. Also, the electrochemical oxidation peak of $\mathrm{HQ}$ was obtained at about $0.139 \mathrm{~V}$ negative potential compared to the bare electrode (Table 1). The potential differences between the anodic and cathodic peaks $\left(\Delta E_{\mathrm{p}}\right)$ at $\mathrm{NSC} / \mathrm{CPE}$ are lower than with the BCPE sensor. These results indicate that the nano-clay has electro-catalytic effect on redox signals of HQ.

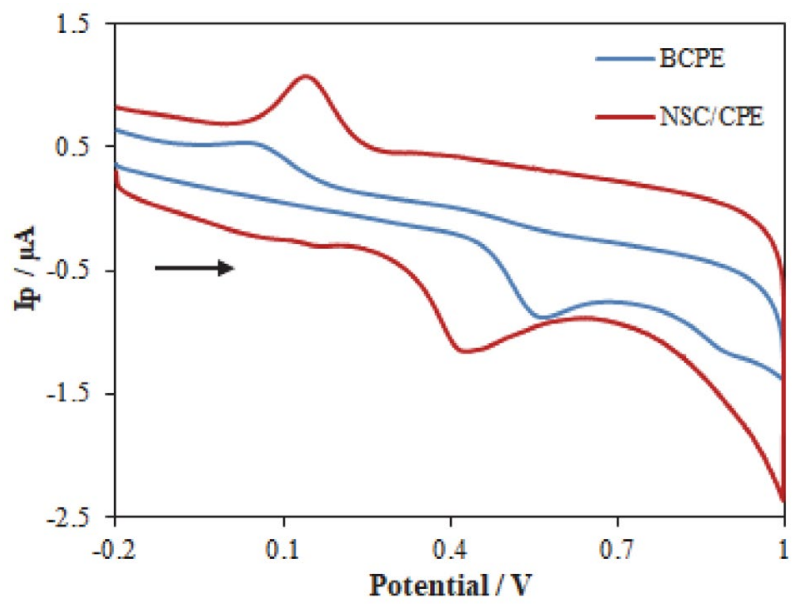

Fig. 3. Cylic voltammograms of $1.0 \times 10^{-4} \mathrm{molL}^{-1} \mathrm{HQ}$ at $\mathrm{BCPE}$ (blue line) and NSC/CPE (red line) in $0.04 \mathrm{M} \mathrm{BR}$ buffer, $\mathrm{pH} 2.0$, scan rate: $0.1 \mathrm{Vs}^{-1}$.

Table 1. Comparison of peak potential and peak current of $1.0 \times$ $10^{-4} \mathrm{molL}^{-1} \mathrm{HQ}$ on BCPE and NSC/CPE by using CV method, $\mathrm{pH}$ : 2.0 BR buffer, scan rate: $0.10 \mathrm{Vs}^{-1}$.

\begin{tabular}{lcccccc}
\hline Electrode & $E_{\mathbf{p}}{ }^{\mathbf{a}} / \mathbf{V}$ & $E_{\mathbf{p}} \mathbf{k} / \mathbf{V}$ & $\Delta E_{\mathbf{p}} / \mathbf{V}$ & $i_{\mathbf{p}}{ }^{\mathbf{a}} / \boldsymbol{\mu} \mathbf{A}$ & $i_{\mathbf{p}} \mathbf{k} / \boldsymbol{\mu} \mathbf{A}$ & $i_{\mathbf{p}} \mathbf{k} / i_{\mathbf{p}} \mathbf{a}$ \\
\hline BCPE & 0.561 & 0.050 & 0.511 & 0.42 & 0.25 & 0.59 \\
NSC/CPE & 0.422 & 0.140 & 0.282 & 0.60 & 0.62 & 1.03 \\
\hline
\end{tabular}

\section{4. Influence of $\mathbf{p H}$}

The effect of $\mathrm{pH}$ on the peak current and peak potential responses of HQ $\left(1.0 \times 10^{-4} \mathrm{molL}^{-1}\right)$ at NSC/CPE sensor was investigated by DPV method in $0.04 \mathrm{molL}^{-1} \mathrm{BR}$ buffer solution (Fig. 4). The number of protons involved in the electrochemical process were sought for using oxidation peak potentials of $\mathrm{HQ}$ in the $\mathrm{pH}$ range of 2.0-5.0 with $1.0 \mathrm{pH}$ unit increments.

The relation between the anodic peak potential, $E_{\mathrm{p}}^{a}$ and $\mathrm{pH}$ was found to be as: $E_{\mathrm{p}}^{a}=-0.0509 \mathrm{pH}+0.4989\left(\mathrm{R}^{2}=\right.$ 0.9977 ). The slope of -0.0509 for oxidation peak is close to theoretical Nernstian value of $-0.059 .{ }^{22}$ This result shows that the transferred numbers of electrons and protons are equal in the oxidation mechanism of $\mathrm{HQ}$.

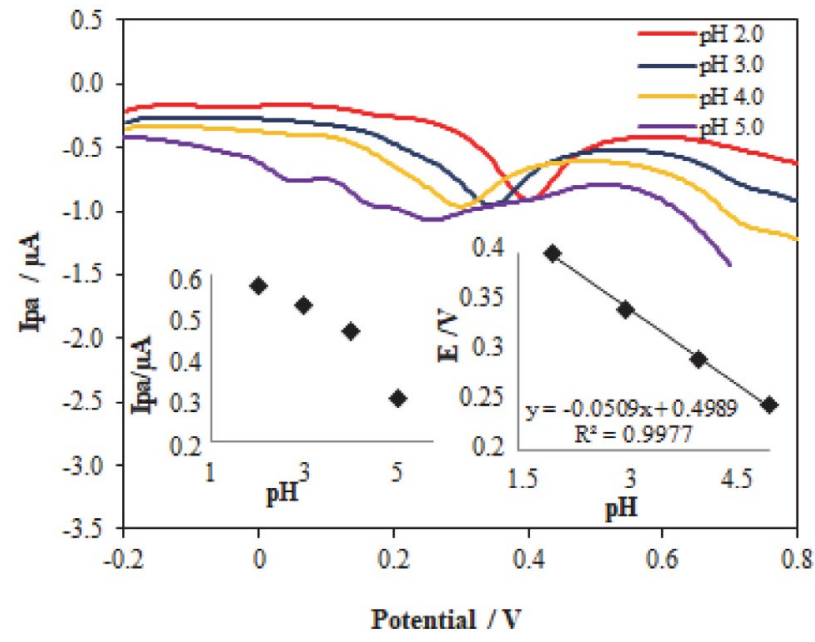

Fig. 4. CVs of $1.0 \times 10^{-4} \mathrm{molL}^{-1} \mathrm{HQ}$ at different $\mathrm{pH}$ values at NSC modifed electrode (Insets are the plots of $\mathrm{pH}$ vs $\mathrm{E}_{\mathrm{p}}$ and $\mathrm{pH}$ vs $i_{\mathrm{p}}$ ).

\section{5. Influence of Scan Rate}

The relationship between the peak currents / potentials and the scan rate gives some important information about whether electrochemical process is adsorption or diffusion controlled. We investigated the effect of scan rate in between $0.005 \mathrm{Vs}^{-1}$ and $0.5 \mathrm{Vs}^{-1}$ on peak current of $1.0 \times$ $10^{-4} \mathrm{molL}^{-1} \mathrm{HQ}$ at $\mathrm{pH} 2.0$ by CV (Fig. 5). The linear rela-

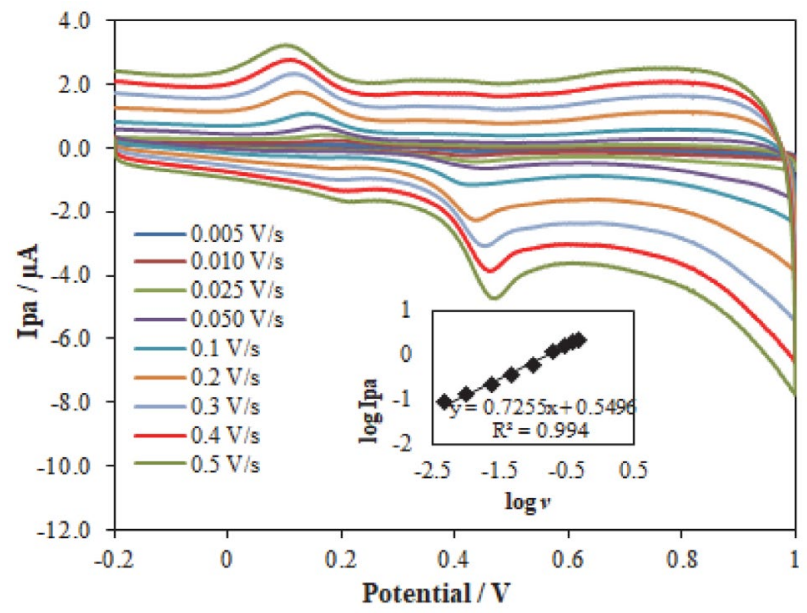

Fig. 5. CVs of $1.0 \times 10^{-4} \mathrm{molL}^{-1} \mathrm{HQ}$ at different scan rates at NSC modified electrode in $0.04 \mathrm{M} \mathrm{BR}$ buffer at $\mathrm{pH} 2.0$ (inset is the plot of $\log i_{\mathrm{p}}$ vs $\log v$ ). 
tionship between anodic oxidation peak current of HQ and scan rate was found according to the following equation:

$$
\log i_{\mathrm{p}}=0.7255 \log v+0.5496
$$

The slope of the function correlation $\log i_{\mathrm{p}}-\log v$ is 0.72 (between 0.5 and 1.0). This results showed adsorption-controlled process of electrochemical reaction. ${ }^{11}$ Also, the oxidation peak potential values were changing with the increasing of scan rate (Fig. 5). This behavior indicates that the electrochemical oxidation of HQ on NSC/ CPE sensor was of a quasi-reversible nature. ${ }^{26}$

Taking into account $\mathrm{pH}$ and scan rate studies, it can be said that the hydroquinone was oxidized by $2 \mathrm{e}^{-} / 2 \mathrm{H}^{+}$to give quinone. Our obtained results are in a good accordance with previous literature data. ${ }^{27}$

\section{6. Electrochemical Detection of $\mathrm{HQ}$ on Modified Electrode}

AdsDPV and AdsSWV methods were used for the determination of HQ on NSC/CPE surface at optimum deposition potential and time. In adsorption studies, it is important to optimize the deposition potential and time. Fig. 6a shows the changes in the range between -0.2 and $+1.0 \mathrm{~V}$ of deposition potential versus peak current for 3.0 $\times 10^{-5} \mathrm{molL}^{-1} \mathrm{HQ}$ in AdsDPV method. Depositon times were changed in the range $0.0-150 \mathrm{~s}$ (Fig. 6b). Similarly, the same parameters were changed for AdsSWV method (Fig. $6 \mathrm{c}$ and d). The graphs obtained from AdsDPV method show that the deposition potential and deposition time are $-0.2 \mathrm{~V}$ and $40 \mathrm{~s}$, respectively. The optimum deposition potential and time were chosen as $0.7 \mathrm{~V}$ and $45 \mathrm{~s}$, respectively, by AdsSWV.

\section{7. Calibration Studies and Validation of Optimized Methods}

The linear relationship between the HQ concentrations and peak currents was studied by using AdsDPV and AdsSWV methods under optimized method and optimum medium conditions. HQ concentration changed in the range between 0.01 and $700 \mu \mathrm{molL}^{-1}$. Fig. $7 \mathrm{a}$ and $\mathrm{b}$ show a perfect linear relationship among $i_{\mathrm{p}}^{\mathrm{a}}$ and $C_{\mathrm{HQ}}$. The linear equations for AdsDPV and AdsSWV are given below:

$\mathrm{i}_{p}^{a}(\mu \mathrm{A})=0.0346 C_{H Q}-0.0448, \mathrm{R}^{2}=0.9993$ (Inset of Fig. 7a). $\mathrm{i}_{p}^{a}(\mu \mathrm{A})=0.0459 C_{H Q}-0.0222, \mathrm{R}^{2}=0.9984$ (Inset of Fig. 7b).

As can be seen in Fig. 7a and b, linear calibration curves were obtained for hydroquinone in the range of $0.01-700 \mu \mathrm{molL}^{-1}$.
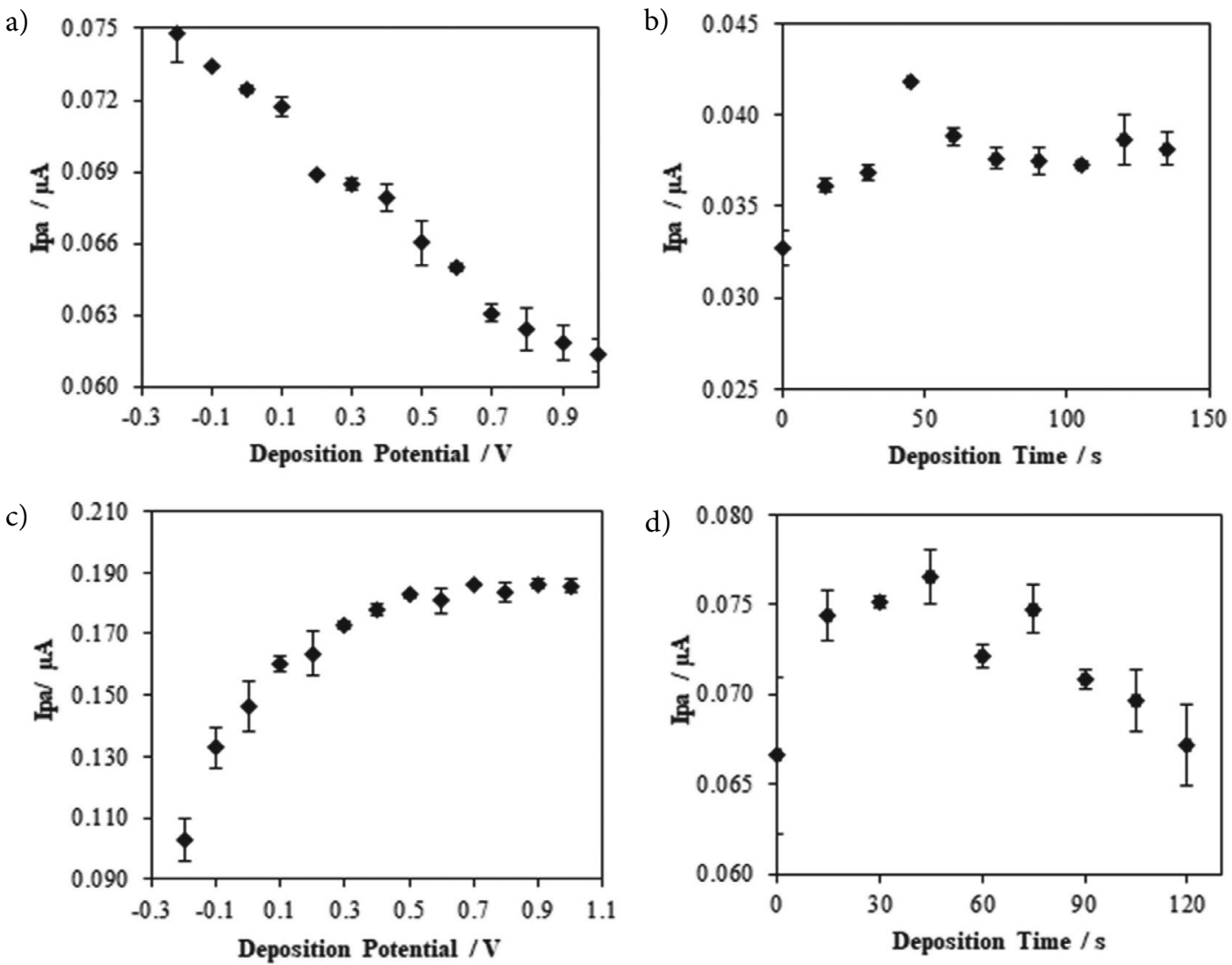

Fig. 6 a. The effect of the deposition potential on the peak current. b. the effect of deposition time on peak current using AdsDPV. c. and d. the graphs obtained using AdsSWV $\left(3.0 \times 10^{-5} \mathrm{molL}^{-1} \mathrm{HQ}\right.$ in $0.04 \mathrm{molL}^{-1} \mathrm{BR}$ buffer $\mathrm{pH} 2.0$. 
a)

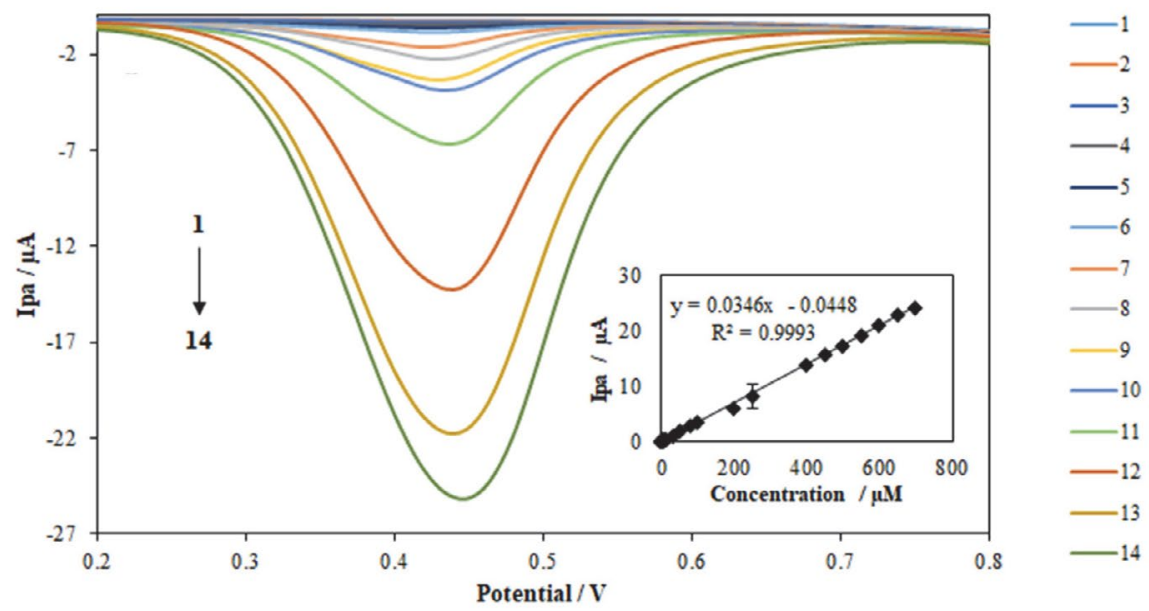

b)

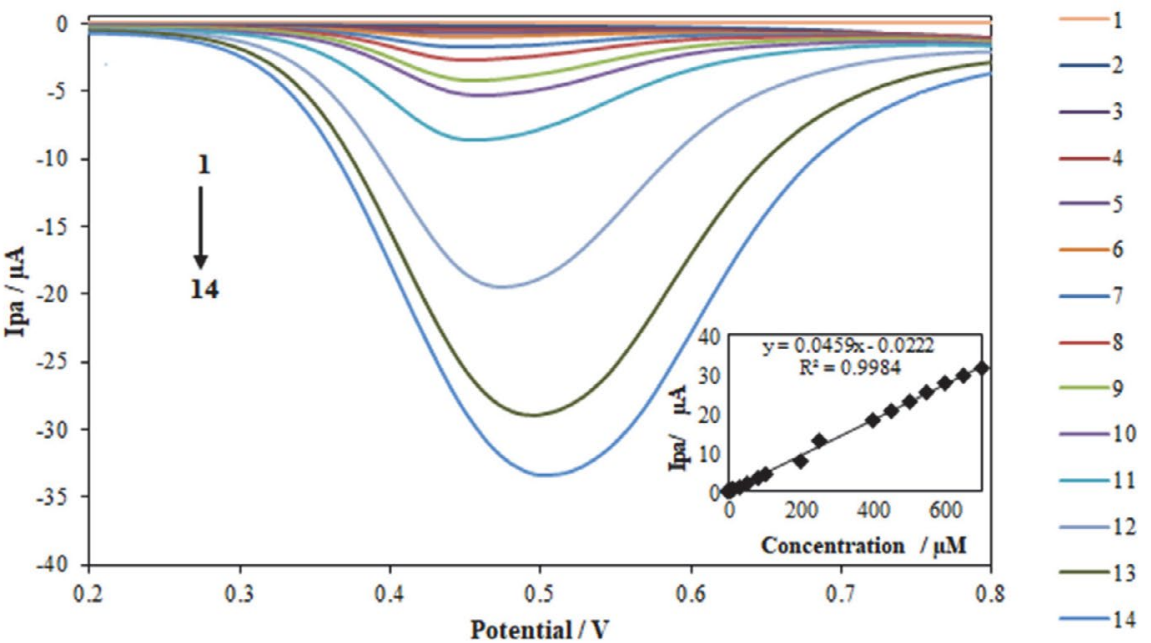

Fig. 7 a. AdsDPV voltammograms of the different concentrations of HQ on NSC modified electrode in $\mathrm{pH} 2.0$ Britton Robinson buffer (1) blank, $(2-14): 1.0 \times 10^{-8}, 1.0 \times 10^{-7}, 1.0 \times 10^{-6}, 5.0 \times 10^{-6}, 1.0 \times 10^{-5}, 3.0 \times 10^{-5}, 5.0 \times 10^{-5}, 8.0 \times 10^{-5}, 1.0 \times 10^{-4}, 2.0 \times 10^{-4}, 4.0 \times 10^{-4}, 6.0 \times 10^{-4}, 7.0 \times$ $10^{-4} \mathrm{molL}^{-1}$; b. AdsSW voltammograms of HQ at different concentrations. (1) blank, (2-14): $1.0 \times 10^{-8}, 1.0 \times 10^{-7}, 1.0 \times 10^{-6}, 5.0 \times 10^{-6}, 1.0 \times 10^{-5}$, $3.0 \times 10^{-5}, 5.0 \times 10^{-5}, 8.0 \times 10^{-5}, 1.0 \times 10^{-4}, 2.0 \times 10^{-4}, 4.0 \times 10^{-4}, 6.0 \times 10^{-4}, 7.0 \times 10^{-4} \mathrm{molL}^{-1}$.

To calculate LOD and LOQ values, the following equations were used:

$$
\mathrm{LOD}=\frac{3 s}{m} \quad, \quad \mathrm{LOQ}=\frac{10 s}{m}
$$

Here, $s$ is the standard deviation for the HQ concentration studied $\left(8.0 \times 10^{-8} \mathrm{molL}^{-1}\right)$, and $m$ is the slope of the calibration graph. According to these equations, LOD and LOQ values were found as $0.01031 \mu \mathrm{molL}^{-1}$ and $0.03438 \mu \mathrm{molL}^{-1}$ for AdsDPV; $0.01096 \mu \mathrm{molL}^{-1}$ and $0.03654 \mu \mathrm{molL}^{-1}$ for AdsSWV, respectively (Table 2 ). According to our literature knowledge, these LOD and LOQ values are the lowest results found up to now.

A comparison table of other literature reports about HQ (Table 3) with our new voltammetric sensor (NSC/ $\mathrm{CPE}$ ) and validation parameters of the proposed new methods (Table 2) are given below:
It is important to investigate the precision of proposed methods and modified electrode by determining the repeatability, reproducibility, and stability of modified electrode. The percent relative standard deviation (RSD\%) values of repeatability of peak current and potential values (intra-day and inter-day) were found by using AdsSWV and AdsDPV methods and it can be seen in Table 2 that the $\%$ RSD values are not higher than $5.0 \%$. These results show a high repeatability. Furthermore, the reproducibility of NSC/CPE sensor was tested by using five electrodes prepared in the same day. The \%RSD values of reproducibility were calculated to be $3.7 \%$ and $4.8 \%$ of the mean value for AdsSWV and AdsDPV, respectively.

To investigate the ageing of NSC/CPE sensor, the signals of HQ were recorded in different days. After ten days, the sensor signal was found to have retained $99.3 \%$ and $99.5 \%$ of its initial value. The electrode gave a response of $98.1 \%$ of the initial response after thirty days. 
Table 2. The statistical results of regression analysis for the determination of HQ

\begin{tabular}{|c|c|c|}
\hline \multirow[t]{2}{*}{ Regression parameters } & \multicolumn{2}{|c|}{ NSC/CPE } \\
\hline & AdsSWV & AdsDPV \\
\hline Potential, V & 0.504 & 0.448 \\
\hline Linear working range, $\mu \mathrm{M}$ & $0.01-700$ & $0.01-700$ \\
\hline Slope of calibration graph, $\mu \mathrm{A} / \mu \mathrm{M}$ & 0.045 & 0.034 \\
\hline Intercept of calibration graph, $\mu \mathrm{A}$ & 0.022 & 0.044 \\
\hline Limit of detection (LOD), $\mu \mathrm{M}$ & 0.01096 & 0.01031 \\
\hline Limit of quantification (LOQ), $\mu \mathrm{M}$ & 0.03654 & 0.03438 \\
\hline Regression coefficient $\left(\mathrm{R}^{2}\right)$ & 0.998 & 0.999 \\
\hline Repeatability of peak potential, RSD $\%$ (intra-day) & 0.9 & 2.6 \\
\hline Repeatability of peak potential, $\mathrm{RSD}^{\star} \%$ (inter-day) & 2.8 & 4.6 \\
\hline Repeatability of peak current, $\mathrm{RSD}^{*} \%$ (intra-day) & 4.7 & 0.5 \\
\hline Repeatability of peak current, $\mathrm{RSD}^{\star} \%$ (inter-day) & 1.8 & 3.4 \\
\hline Reproducibility of peak current, RSD $\%$ & 3.7 & 4.8 \\
\hline Reproducibility of peak potential, $\mathrm{RSD}^{\star} \%$ & 1.7 & 0.5 \\
\hline
\end{tabular}

${ }^{*} \mathrm{RSD}$ is the relative standard deviation of 5 replications.

Table 3. The comparison of the performances of various electrochemical sensors for HQ analysis.

\begin{tabular}{|c|c|c|c|c|c|}
\hline Sensor & Technique & Linearity range $\mu \mathrm{molL}^{-1}$ & LOD $\mu \mathrm{molL}{ }^{-1}$ & Application & Reference \\
\hline $\mathrm{NiO} / \mathrm{NPs}$ & SWV & $0.1-500$ & 0.05 & tap and wastewater & 18 \\
\hline eosin Y film GCE & DPV & $1-130$ & 0.14 & local tap water & 22 \\
\hline $\mathrm{GR}-\mathrm{TiO}_{2} / \mathrm{GCE}$ & DPV & $0.5-100$ & 0.082 & tap and lake water & 23 \\
\hline single-walled carbon nanohorn/GCE & LSV & $0.5-100$ & 0.1 & tap water & 24 \\
\hline Au-G nanocomposite & DPV & $1-100$ & 0.2 & tap water & 25 \\
\hline \multirow[t]{2}{*}{ NSC/CPE } & AdsDPV & $0.01-700$ & 0.01031 & Cream & This \\
\hline & AdsSWV & $0.01-700$ & 0.01096 & & paper \\
\hline
\end{tabular}

(NiO: Nickel oxide nanoparticles; $\mathrm{TiO}_{2}$ : Titanium dioxide nanoparticles; NPs: nanoparticle, GCE: glassy carbon electrode, GR: graphene, Au-G: gold-graphene)

After all experiments, the newly proposed sensor was kept at $+4{ }^{\circ} \mathrm{C}$.

\section{8. Interferences}

In order to confirm the selectivity of the NSC/CP electrode, the influence of possible impurities was investigated for proposed methods with NSC/CP electrode. To this end, synthetical solutions of $0.1 \mu \mathrm{molL}^{-1} \mathrm{HQ}$ were mixed with proper amounts of $\mathrm{Na}^{+}, \mathrm{Co}^{2+}, \mathrm{K}^{+}, \mathrm{Mg}^{2+}, \mathrm{Cl}^{-}$, $\mathrm{NO}_{3}{ }^{-}, \mathrm{Cu}^{2+}, \mathrm{Fe}^{3+}$, with the intent of adjusting their concentrations to $10 \mu \mathrm{molL}^{-1}$ (100 times higher than $\mathrm{HQ}$ ); $\mathrm{Ni}^{2+} 5$ $\mu \mathrm{molL}^{-1}$ (50 times higher than HQ); uric acid (UA) and ascorbic acid (AA) $1 \mu \mathrm{molL}^{-1}$ (10 times higher than HQ).
Peak currents obtained for pure HQ and samples mixed with other contaminants were compared. $\mathrm{NaCl}, \mathrm{Mg}(-$ $\left.\mathrm{NO}_{3}\right)_{2}, \mathrm{KCl}, \mathrm{Co}\left(\mathrm{NO}_{3}\right)_{2}, \mathrm{Ni}\left(\mathrm{NO}_{3}\right)_{2}, \mathrm{Fe}\left(\mathrm{NO}_{3}\right)_{3}, \mathrm{Cu}\left(\mathrm{NO}_{3}\right)_{2}$, $\mathrm{AA}$ and UA caused less than $5 \%$ interference effect for both AdsSWV and AdsDPV methods. The results show that both methods with NSC/CP electrode exhibited good selectivity. Interference effect was at an acceptable level from analytical point of view.

\section{9. Real Sample Analysis and Recovery}

Using the developed electrode, the cosmetic sample (Expigment cream) was analyzed for hydroquinone content. The accuracy of developed methods was tested by re-

Table 4. Main recovery results and the relative standard deviations for the determination of HQ in pharmaceutical cream

\begin{tabular}{lccrrr}
\hline Method & Added $(\boldsymbol{\mu g})$ & Found $(\boldsymbol{\mu g})$ & Average & Recovery \% & RSD \% \\
\hline AdsSWV & 0.54 & $0.56 ; 0.52 ; 0.51 ; 0.55 ; 0.50$ & $0.53 \pm 0.03$ & 98.6 & 5.58 \\
& 3.36 & $3.52 ; 3.54 ; 3.46 ; 3.50 ; 3.57$ & $3.52 \pm 0.04$ & 104.6 & 1.21 \\
& 12 & $10.13 ; 9.86 ; 9.94 ; 10.12 ; 10.27$ & $10.08 \pm 0.17$ & 100.8 & 1.71 \\
AdsDPV & 0.54 & 0,$55 ; 0,55 ; 0,57 ; 0,56 ; 0,57$ & $0.56 \pm 0.01$ & 104.6 & 1.72 \\
& 3.36 & $3.64 ; 3.65 ; 3.62 ; 3.64 ; 3.66$ & $3.64 \pm 0.01$ & 108.6 & 0.47 \\
& 12 & $12.15 ; 11.83 ; 11.93 ; 12.24 ; 12.33$ & $12.09 \pm 0.21$ & 105.5 & 6.56 \\
\hline
\end{tabular}


covery studies. Recovery studies were performed by analyzing the cosmetic sample enriched with known amounts of HQ using proposed methods (Table 4). The recovery data indicate that the proposed methods can be used safely in cosmetic samples with presented excipients. According to these results, the proposed methods have definite precision and accuracy.

\section{Conclusion}

A simple electrochemical sensor made up of nanoclay modified carbon paste electrode was developed for analysis of hydroquinone in cosmetic sample. The sensor has the advantages of high sensitivity, electrocatalytic effect, ease of preparation, good stability, practical surface renewal, high precision, low cost, large linear range, and low limit of detection. The electrode proved to be applicable to HQ assay in real sample. The developed methods and NSC modified electrode were compared to previously reported results.

\section{References}

1. Y. Zhang, J. Huang, G. Jiang, Z. Song, Z. Xie, Sensors \& Transducers, 2014, 174 (7), 261-267. DOI:10.1111/ics.12228

2. J. S. Jeon, B. H. Kim, S. H. Lee, H. J. Kwon, H. J. Bae, S. K. Kim, J. A Park, J. H. Shim, A. M. Abd El-Aty, H. C. Shin, , Int. J. Cosmet. Sci., 2015, 37, 567-573.

3. M. F. Pistonesi, M. S. Di Nezio, M. E. Centurion,M. E. Palomeque, A. G. Lista, B. S. Fernandez Band, Talanta, 2006, 69, 1265-1268. DOI:10.1016/j.talanta.2005.12.050

4. Y. Chao, X. Zhang, L. Liu, L. Tian, M. Pei, W. Cao, Microchim Acta, 2015, 182, 943. DOI:10.1007/s00604-014-1415-2

5. R. Khoshneviszadeh, B. S. Fazly Bazzaz, M. R. Housaindokht, A.Ebrahim-Habibi, O. Rajabi, Iran. J. Pharm. Res., 2015, 14 (2), 473-478.

6. M. R. Elghobashy, L. I. Bebawy, R. F. Shokryb, S. S. Abbas, Spectrochim. Acta Part A: Molecular and Biomolecular Spectroscopy, 2016, 157, 116-123.

DOI:10.1016/j.saa.2015.12.019

7. K. Jurica, I. B. Karačonji, S. Šegan, D. M. Opsenica, D. Kremer, Arh Hig Rada Toksikol, 2015, 66, 197-202.

DOI:10.1515/aiht-2015-66-2696
8. C. Desiderio, L. Ossicini, S. Fanali, J. Chromatogr. A, 2000, 887, 489-496. DOI:10.1016/S0021-9673(99)01197-8

9. A. Kumara, B.E. Kumara Swamy, J. Electroanal. Chem. 2017, 799, 505. DOI:10.1016/j.jelechem.2017.06.026

10. P. S. Ganesh, B. Eshwaraswamy, K. Swamy, Anal. Bioanal. Electrochem., 2016, 8, 615-628.

11. P. S. Ganesh, B.E. Kumara Swamy, J. Electroanal. Chem., 2015, 756, 193-200. DOI:10.1016/j.jelechem.2015.08.027

12. L. A. Alshahrani, X. Li, H. Luo, L. Yang, M. Wang, S. Yan, P. Liu, Y. Yang, Q. Li, Sensors, 2014, 14(12), 22274-22284. DOI:10.3390/s141222274

13. L. Zheng, L. Xiong, Y. Li, J. Xu, X. Kang, Z. Zou, S. Yang, J. Xia, Sens. Actuators B, 2013, 177, 344.

DOI:10.1016/j.snb.2012.11.006

14. Y. Zhang, J. B. Zheng, Electrochim. Acta, 2007, 52, 7210-7216. DOI:10.1016/j.electacta.2007.05.039

15. J. Tashkhouriana, M. Daneshi, F. Nami-Anaa, M. Behbahani, A. Bagheri, J. Hazard. Mater., 2016, 318, 117-124. DOI:10.1016/j.jhazmat.2016.06.049

16. H. Filik, A. A. Avan, S. Aydar, Food Anal. Methods, 2016, 9, 2251-2260. DOI:10.1007/s12161-016-0420-y

17. J. Huang, Z. Xie, Z. Xie, S. Luo, L. Xie, L. Huang, Q. Fan, Anal. Chim. Acta, 2016, 913, 121-127.

DOI:10.1016/j.aca.2016.01.050

18. H. Soltani, A. Pardakhty, S. Ahmadzadeh, J. Mol.Liq., 2016, 219, 63-67. DOI:10.1016/j.molliq.2016.03.014

19. M. Pekin, D. E. Bayraktepe, Z. Yazan, Ionics, 2017, 23, 34873495. DOI:10.1007/s11581-017-2132-8

20. D. E. Bayraktepe, T. Yanardağ, Z. Yazan, A. Aksüt, Rev. Roum. Chim., 2015, 60(4), 287-295.

21. H. Beitollah, M. Goodarzian, J. Mol. Liq., 2012, 173, 137-143. DOI:10.1016/j.molliq.2012.06.026

22. J. He, Anal. Methods, 2014, 6, 6494-6503. DOI:10.1039/C4AY00575A

23. Y. Zhang, Sens. Actuators B, 2014, 204, 102-108. DOI:10.1016/j.snb.2014.07.078

24. S. Zhu, W. Gao, L. Zhang, J. Zhao, G. Xu, Sens. Actuators B, 2014, 198, 388-394. DOI:10.1016/j.snb.2014.03.082

25. X. Ma, Z. Liu, C. Qiu, T. Chen, H. Ma, Microchim. Acta, 2013, 180, 461-468. DOI:10.1007/s00604-013-0949-Z

26. A. J. Bard and LR. Faulkner, Electrochemical Methods, Wiley, New York, 1980.

27. Z. Guohua, L. Mingfang, H. Zhonghua, L. Hongxu, C. Tongcheng, J. Mol. Catal. A: Chem., 2006, 255, 86-91. DOI:10.1016/j.molcata.2006.03.039 


\section{Povzetek}

V tej raziskavi smo razvili preprost in občutljiv elektrokemijski nanosenzor za analizo hidrokinona, osnovan na s sepiolitno glino modificiranem senzorju z ogljikovo pasto, za uporabo pri diferencialni pulzni adsorpcijski inverzni voltametriji in pri adsorpcijski inverzni voltametriji s pravokotnimi pulzi. Površinsko morfologijo senzorjev smo okarakterizirali $\mathrm{z}$ vrstično elektronsko mikroskopijo, elektrokemijsko impedančno spektroskopijo in ciklično voltametrijo. Elektrokemijske redoks lastnosti hidrokinona smo raziskali s ciklično voltametrijo. Oksidacijski maksimalni tok za hidrokinon se pri diferencialni pulzni adsorpcijski inverzni voltametriji in pri adsorpcijski inverzni voltametriji s pravokotnimi pulzi linearno spreminja v koncentracijskem območju $0,01-700 \mu \mathrm{molL}^{-1}$ za prvo in $0,01-700 \mu \mathrm{molL}^{-1}$ za drugo metodo. Določili smo odlične meje zaznave (LOD) in meje določitve (LOQ), in sicer $0,01096 \mu \mathrm{molL}^{-1}$ ter $0,03654 \mu \mathrm{molL}^{-1} \mathrm{za} \mathrm{dife-}^{-1}$ rencialno pulzno adsorpcijsko inverzno voltametrijo in $0,01031 \mu \mathrm{molL}^{-1}$ ter $0,03438 \mu \mathrm{molL}^{-1} \mathrm{za}$ adsorpcijsko inverzno voltametrijo s pravokotnimi pulzi. Dodatno smo razviti senzor uporabili za določitev hidrokinona v kozmetični kremi z zadovoljivimi rezultati. 